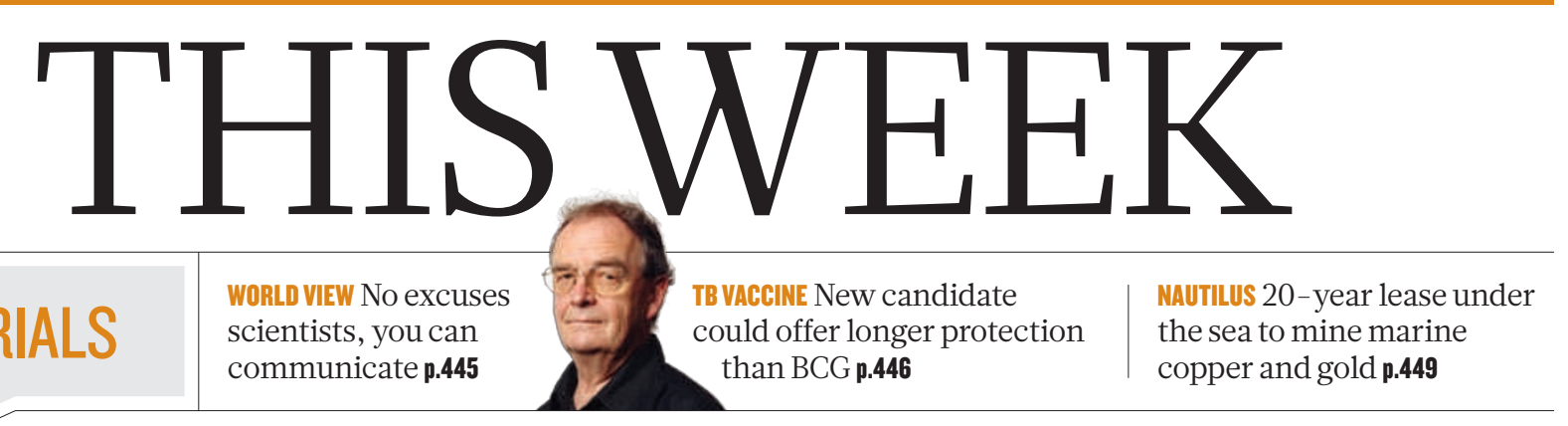

EDITORIALS

scientists, you can communicate $\mathbf{p . 4 4 5}$

\title{
Vive la révolution
}

\section{Tunisia's nascent democracy, promoting justice, human rights and intellectual freedom, needs to be celebrated and encouraged.}

$\mathrm{T}$ The revolution in Tunisia cost more than 100 lives and there is no guarantee at this early stage that the fledgling democracy that has emerged will prosper as many wish it to. But turmoil is to be expected immediately after any revolution, and for the moment there is much to celebrate.

Tunisian scientists are relishing their nation's opportunity as a laboratory, not just for democracy and human rights in the Arab world, but also because the pay-offs from education and science are greatest when fundamental freedoms are respected.

The link between democracy and science as a precondition for progress in the Arab world was clearly articulated in 2003 in a report called Building a Knowledge Society, part of the Arab Human Development Reports and "written by Arabs for Arabs" by a group of more than 100 scholars and experts. It made the forceful argument that political deficiencies, such as a lack of respect for human rights, and the guaranteeing of these rights through good governance, were the primary obstacle to building knowledge societies - based on research in science and the humanities - in the Arab world. Poor levels of investment in science and education were secondary. Nader Fergany, lead author of the reports, made the case that knowledge societies could flourish only in open societies with democratic institutions that fully respected human rights such as freedoms of speech and freedom of association (see Nature 444, 33-34; 2006).

\section{INTERNATIONAL MYOPIA}

Tunisia is perhaps a case in point. The ousted regime of President Zine el-Abidine Ben Ali was expert at double speak, and preached the benefits of greater human rights while simultaneously crushing them. Speaking to Nature since the revolution, Tunisian researchers tell how it was almost impossible to convince foreign colleagues that the positive image of their country common among outsiders was myopic. The realpolitik embrace of the Tunisian administration by the international community, which saw it as a rock of stability against radical Islam in the Middle East and North Africa, also reinforced its perceived legitimacy.

For years, the regime also projected an image of Tunisia as a country committed to science. From the outside looking in, it was hard to disagree. Tunisia invested more (as a percentage of gross domestic product) than many of its Arab neighbours, and notched up relatively favourable increases in the numbers of researchers and articles published.

So it is both sobering and valuable, particularly given the arguments of the Arab Human Development Reports, to hear the testimony of Tunisian researchers, who argue that much of the claimed success of Tunisian science in the past decade was, on a deeper level, a mirage. And that the achievements that were made, were largely despite the Ben Ali regime rather than because of it. In fact, they tell how through totalitarian governance and the denial of freedoms, the regime imposed an 'intellectual blockage' at every level of university life, which disempowered researchers and stifled the development of a dynamic research and innovation system (see page 453). Indoctrinated not to criticize the system, young researchers have also failed to develop independent minds. As one Tunisian researcher puts it: "Scientists need the freedom to stand back from dogma if they are to innovate."

Tunisia's science carried other hallmarks of authoritarian regimes, such as the dearth of social-science research. Those who silence critics have little interest in encouraging branches of enquiry that could hold the regime up to scrutiny. Another hallmark was the practice of awarding posts to the politically loyal, rather than on merit. This should not take long to remedy, however, because Tunisia is a small country, and its scientists know who are the best and brightest.

Tunisians are optimistic that a new era is at
"Tunisians are optimistic that a new era is at hand." hand, and that the creation of an open society where democracy, human rights and academic freedom flourish is within reach. Researchers there seem convinced, like Fergany, that greater freedoms and good science and education go hand-in-hand. In the heady aftermath of a revolution, such aspirations may sound all too sunny. The road ahead is uncertain, and reforms will take years, but there is every reason to be optimistic that the conditions for change are better now than at any time since the country gained independence in 1956. Many Tunisians are also well educated, and they want their revolution to succeed. Now is not the time for punditry on its chances of success; the hour is one to celebrate what has already been achieved, and to encourage the fledgling democracy, for example, by encouraging scientific cooperation.

\section{WRONG SIDE OF HISTORY}

Most of Tunisia's scientific cooperation and links are with France, its former colonial master across the Mediterranean Sea. A stalwart ally of Ben Ali, the French government utterly discredited itself in the eyes of Tunisians in its response to the revolution - putting itself on the wrong side of history; even offering the dictator the country's expertise in riot control. But the diaspora of Tunisian and Franco-Tunisian academics in France now have an opportunity to speak out and influence what should happen next. So too do the French national research agencies - and the European Union - which have long had formal collaboration programmes with Tunisia.

Last week, Nature asked Faouzia Charfi, Tunisia's secretary of state for higher education in the transition government and a well-known human-rights advocate, how researchers elsewhere could help. She said: "When researchers in our country solicit them with solid research proposals, help them. Help our researchers to also have the possibility to take part in conferences and to work outside the country. A Tunisian passport, without a visa, doesn't open doors to many countries. Open up to us your borders, so that we can speak together the same language, the language of science, and the language of human-rights values in which I have always believed." - 